\title{
Ozone improves autogenous graft healing in experimental diabetes mellitus: A morphometric and immunohistochemical study
}

\author{
Aysan Lektemur Alpan(0000-0002-5939-4783) ${ }^{\alpha}$, Hülya Toker(0000-0003-2168-0853) ${ }^{\beta}$, Hatice Özer(0000-0001-6479-3626) ${ }^{\gamma}$
}

Selcuk Dent J, 2020; 7: 44-53 (Doi: 10.15311/selcukdentj.419582)

Bassuru Tarihi: 29 Nisan 2018 Yayına Kabul Tarihi: 17 Ocak 2019

\section{ABSTRACT \\ Ozone improves autogenous graft healing in experimental diabetes mellitus: A morphometric and immunohistochemical study}

Background: Diabetes mellitus (DM) is a metabolic disorder which plays crucial role in the pathogenesis of periodontitis. Ozone have several actions such as antimicrobial, immunostimulating, antihypoxic effects, and activates antioxidant enzymes and angiogenesis. The aim of this study is to investigate the effect of gaseous ozone on bone healing in diabetic rat calvarial defects treated with autogenous bone graft, morphometrically and immunohistochemically.

Material and Methods: Diabetes was induced and critical size defects were created on rats. Study groups: 1-Empty defect (Control, $n=14$ ) group, 2-Autograft (AG, $n=14$ ) group, 3-Empty defect+ozone therapy (Control+Ozone, $n=14$ ) group, 4Autograft+ozone application ( $A G+O z o n e, n=14$ ) group. Gaseous ozone was applied on the operation day and the following 2 weeks daily (140ppm @ 2L/d, $2.24 \mathrm{mg}$ ). Total bone area was measured. Osteocalcin and Bone morphogenic protein-2 protein expressions were evaluated.

Results: Control and Control+Ozone groups had no osteoclast and residuel lacunae during the study. Osteoblasts in $A G+O z o n e$ group were higher than $A G$ group at 4 th week $(p>0.05)$. $A G+O z o n e$ group had more total bone area than $A G$ group at 4th week. AG+Ozone group revealed more BMP-2 immune positivity compared to the other groups. Osteocalcin immune positivity in AG groups was higher than those of the Control groups.

Conclusion: Within the limitations of this study, gaseous ozone application decreased osteoclast number and increased osteoblast number and bone regeneration, especially, in early stages of bone regeneration in diabetic rats.

\section{KEYWORDS}

Autograft, bone regeneration, calvarial defect, experimental diabetes mellitus, ozone

Diabetes mellitus (DM) is a metabolic disorder which plays crucial role in the pathogenesis of periodontitis. DM has bidirectional relationship with the development, progression and severity of periodontitis. ${ }^{1} \mathrm{DM}$ alters bone metabolism with different pathways including hyperglycemia and increased advanced glycation end

\section{öz}

Ozonun deneysel diabetes mellitustta otojen greft iyileşmesini artırması: Morfometrik ve immünhistokimyasal çalışma

Amaç: Diabetes mellitus (DM), periodontitis patogenezinde önemli rol oynayan bir metabolik bozukluktur. Ozonun antimikrobiyal, immünostimülasyon, antihipoksik etkileri gibi çeşitli etkileri vardır ve antioksidan enzimleri ve anjiyogenezi aktive eder. Bu çalışmanın amacı otojen kemik grefti ile tedavi edilen diyabetik sıçan kalvaryal defektlerinde uygulanan ozonunun kemik iyileşmesi üzerine etkisini morfometrik ve immünhistokimyasal olarak incelemektir.

Gereç ve Yöntemler: Sıçanlarda diyabet indüklendi ve kalvaryal defektler oluşturuldu. Çalışma grupları: 1-Boş defekt (Kontrol, $n=$ 14) grubu, 2-Otogreft (AG, $n=14$ ) grubu, 3-Boş defekt + ozon tedavisi (Kontrol + Ozon, $n=14$ ) grubu, 4-Otogreft + Ozon uygulaması ( $A G+$ Ozon, $n=14)$ grubu. Operasyon gününde ve sonraki 2 haftada gaz ozon (140ppm2L / d, $2.24 \mathrm{mg}$ ) kalvaryal bölgeye uygulandı. Toplam kemik alanı ölçüldü. Osteokalsin ve Kemik morfojenik protein-2 protein ekspresyonları değerlendirildi.

Bulgular: Kontrol ve Kontrol + Ozon gruplarında çalışma süresince osteoklast ve rezidüel lakün gözlenmedi. $A G+O z o n$ grubunda osteoblastlar, 4. haftada AG grubundan daha fazla gözlendi $(p>0.05)$. $A G+$ Ozon grubunun 4 . haftada $A G$ grubundan daha fazla toplam kemik alanı vardı. $A G+O z o n$ grubu diğer gruplara göre daha fazla BMP-2 immün pozitifliği saptadı. AG gruplarında osteokalsin immün pozitifliği, kontrol gruplarından daha yüksekti.

Sonuç: Bu çalışmanın kısıtıııkları dahilinde, gaz ozon uygulaması, özellikle diyabetik sıçanlarda kemik rejenerasyonunun erken aşamalarında osteoklast sayısını azaltarak ve osteoblast sayısını artırarak kemik rejenerasyonunu artırmıştır.

\section{ANAHTAR KELIMELER}

Otogreft, kemik rejenerasyonu, kalvaryal defekt, deneysel diabetes mellitus, ozon

product (AGE) formation, reactive oxygen species (ROS) generation, and inflammation. ${ }^{2}$

Peri-implantitis and also periodontitis can be defined as an infectious disease associated to an inflammatory process involving periodontal soft tissues, and causing bone loss around an

\footnotetext{
${ }^{\alpha}$ Pamukkale University, Faculty of Dentistry, Department of Periodontology, Denizli, Turkey

${ }^{\beta}$ Health Sciences University Gulhane Faculty of Dentistry, Department of Periodontology, Ankara, Turkey

${ }^{\vee}$ Cumhuriyet University, Faculty of Medicine, Department of Pathology, Sivas, Turkey
} 
osseointegrated implant and/or teeth. ${ }^{3}$ Although, different graft material were used for bone defects, autografts are still remain the 'gold standard' in reconstructing bone defects as it combines all properties required in a bone-graft material: osteoinduction (bone morphogenic proteins and other growth factors), osteogenesis (osteoprogenitor cells) and osteoconduction (scaffold) but remodeling it suffers from inadequate tissue availability, associated donor site morbidity ${ }^{4,5}$ and unpredictable graft resorption. ${ }^{6}$ Many treatment modalities have been used to improve the regenerative capacity of the autografts such as platelet rich plasma ${ }^{7}$, platelet rich fibrin ${ }^{8}$, alendronate application $^{9}$, and more recently ozone therapy. ${ }^{10}$

Ozone (triatomic oxygen and trioxygen) is an allotropic form of oxygen occurring naturally in the Earth's atmosphere and known as the third strongest oxidizing agent in the World. ${ }^{11,12}$ There are several actions of ozone on human body such as antimicrobial effect against bacteria, fungi, and viruses, immunostimulating effect by stimulating proliferation of immunocompetent cells and synthesis of immunoglobulins and activating function of macrophages, antihypoxic effect by improving transportation of oxygen in blood, and activating antioxidant enzymes and activating angiogenesis. ${ }^{11,13}$

Ozone therapy in dentistry is gaining a place in everday modern practice and is investigated in mostly its antimicrobial effects. ${ }^{14,15}$ There are a few studies in the literature on the effects of ozone bone healing. ${ }^{10,16-18}$ In our previous study, ozone efficacy on bone healing was investigated in xenograft treated calvarial defects in diabetic rats. Rats were diveded into four groups following: Contol, Control+Ozone, Xenograft, Xenograft+Ozone. Xenograft+Ozone group was revealed more total bone area and new bone area at 4th week comparing the Xenograft group. Thus residuel graft material was decreased in Xenograft+Ozone group. Osteocalcin and bone morphogenic protein-2 (BMP2) immunopositivity were higher than other groups. ${ }^{19}$

Effects of DM to bone itself could impair physiological bone regeneration process. Thus antimicrobial, immunostimulating, antihypoxic and biosynthetic effects of ozone can increase oxygene in tissues and improve the healing phase in diabetic state. Referring the current literature, data regarding the effect of the ozone application to autograft healing in the diabetic condition is not reported. Thus the aim of this study was to investigate the effect of the topical gasseous ozone therapy on bone graft healing in diabetic rats with calvarial defects using histomorphometry and immunohistochemistry.

\section{MATERIALS AND METHODS}

\section{Animals}

Experimental protocol was approved by the Animal Ethics Committee of Cumhuriyet University Faculty of Medicine with a document number 65202830/130. Fifty-six aged 12 weeks Wistar male rats (mean weight $320-400 \mathrm{~g}$ ) were used. . Throughout the experiment, the animals were kept in individual cages in temperature-controlled rooms with $12 \mathrm{~h}$ day/night cycles and free to access to water and pellet shaped food. Diabetes was induced in all rats and all rats were recieved critical size calvarial defects (CSD).

\section{Induction of diabetes}

Experimental diabetes was induced by an intraperitoneal injection of $50 \mathrm{mg} / \mathrm{kg}$ body weight streptozotocin (STZ) (Santa Cruz Biotechnology Inc., Heidelberg, Germany) dissolved in $4^{\circ} \mathrm{C}$ pure water according to the manufacturer's instructions. The rats were fed $5 \%$ glucose solution (12-24h) to prevent development of possible hypoglycemia. $72 \mathrm{~h}$ later fasting blood glucose levels were monitored using a glucometer (CareSens II, Pharmaco (NZ) Ltd, Auckland, New Zelland) and rats with blood glucose concentration greater than $300 \mathrm{mg} / \mathrm{dl}$ were included in the study.

The animals were randomly divided into six groups as follows:

- Empty defect (Control) group $(n=14)$;

- Autogenous bone graft (AG) group $(n=14)$;

- Empty defect and ozone application (Control+Ozone) group $(n=14)$;

- Autogenous bone graft and ozone application (AG+Ozone) group $(n=14)$

\section{Surgical procedures}

The rats were fully anesthetized with an intramuscular 40mg/kg ketamine (Eczacibasi Ilac Sanayi, Istanbul, Turkey), the site of surgery was shaved and disinfected with povidone-iodine, and a midline calvarial incision was made in the skull from the nasal to the occipital region. After careful exposure of the flat surface of the cranium, a $5 \mathrm{~mm}$ calvarium defect was created at the right side of saggital suture using a trephine drill (Mis Implant Tech, Shlomi, Israel) under continuous irrigation with sterile saline. AG was harvested from the left side of cranium using a trephine drill (and was ground with manuel bone crusher (Schwert, Seitingen/Oberflacht, Germany) than implanted in to CSD of $A G$ and $A G+O z o n e$ groups. The periosteum was closed using a resorbable synthetic polyglactin suture (Ecosorb Vigilenz, Penang, Malaysia) before skin closure with 4-0 silk suture (Dogsan llac Sanayi, Istanbul, Turkey) .The body weight of rats was measured periodically (baseline, 4th, 8th week ). Blood samples were withdrawn by means of tail artery prick method to measure blood glucose level ( $\mathrm{mmol} / \mathrm{L}$ ) using 
glucometer (CareSens II, Pharmaco (NZ) Ltd, Auckland, New Zelland) periodically (baseline, 3rd, 10th, 20th, 30th, 40th, 55th days). At different time points of healing (4 or 8 weeks), the animals were euthanized by injecting an overdose of $3 \%$ pentobarbital sodium, and then the calvarials and the surrounding tissue were removed from the bodies.

\section{Ozone application}

Ozone was applied using a generator (Prozone, W \& $\mathrm{H}$, Bürmoos, Austria) with a handpiece to. Control+Ozone and $A G+$ Ozone groups. The ozone groups were received 140ppm @ 2L/d, $2.24 \mathrm{mg} 30 \mathrm{~s}$ ozone before the periosteum was closed and $90 \mathrm{~s}$ over the scalp for 14 days.

\section{Histological analysis}

The calvarial samples defects and the surrounding tissue were fixed in $10 \%$ neutral formalin for $24 \mathrm{~h}$ then demineralized in $10 \%$ ethylene diamine tetraacetic acid for 2 to 4 weeks. Each specimen was divided at the center of the defect area and embedded in to parafin wax perpendicularly. A $6 \mu \mathrm{m}$ thickness sections were obtained and stained with hematoxylin and eosin (HE). The histhologic analysis was performed by a single examiner (HO) who was masked from the samples' identities using light microscope (Eclipse 80i, Nikon, Tokyo, Japan). Osteoclasts which are large cells with multiple nuclei near the border of the resorption surface, resorption lacunaes and osteoblasts which are cubiodal cells adjacent to defect and graft border were counted.

\section{Histomorphometric evaluation}

Each specimen was stained with $\mathrm{HE}$, the same area was photographed using a digital camera connected to a light microscope with an original magnification $\times 4$. All photographs were then transferred into a PC environment and analyzed using a program (Clemex Technologies, Quebec, Canada) by another examiner (ALA) who was masked from the samples' identities. The amount of total bone area $\left(\mathrm{mm}^{2}\right)$ was measured as described. ${ }^{19}$

\section{Immunohistochemical analysis}

Osteocalcin and BMP-2 automated immuohistochemistry were performed using the Rabbit polyclonal anti-BMP-2 antibody (Millipore, Massachusetts, USA) and rabbit polyclonal antiosteocalcin antibody (Millipore, Massachusetts, USA) on the Benchmark XT platform (Ventana Medical Systems, Tucson, Arizona, USA).The procedures were accomplished with ultraView DAB detection kit (Ventana Medical Systems, Tucson, Arizona, USA) according to the manufacturer's protocol. Each specimen was used as positive and negative controls, respectively. A semi-quantitave scoring system was used to evalute immunohistochemical data following: "-"staining 0-10\% immunopositivity, "+" staining from $10 \%-25 \%$, "++" staining from $25 \%-50 \%, "+++$ " staining from $50 \%-70 \%$ and " ++++ " staining for more than $75 \%$. ${ }^{20}$

\section{Statistical analysis}

Statistical analyses were performed with SPSS ver. 22 (IBM Corporation, New York, USA). To expose the data distrubition Kolmogorov-Smirnov test was performed. One-way ANOVA; post hoc Tukey test were used to compare four groups. Independent sample $t$ test was applied to compare two groups. The data were presented as mean \pm standard deviation and $p<0.05$ regarded as statistically significant.

\section{RESULTS}

There were no surgical complications during the operation and the rats were well tolerated the surgical treatment during the experiment. However, one rat from Control, Control+Ozone and AG+Ozone groups at the 4th week and one rat from all groups at the 8th week was died. Weight loss in rats was continued during the experiment. Weight of rats $(193.31 \pm 10.49 \mathrm{~g})$ in 60th day was statistically lower than those of 30th day $(250.70 \pm 32.55 \mathrm{~g})$ and baseline $(356.85 \pm 16.49 \mathrm{~g})$ $(p<0.05)$. Diabetes depended hyperglycaemia was continued during the experiment. blood glucose levels of rats in 30th day $(444.10 \pm 31.01 \mathrm{mg} / \mathrm{dl})$ and 60th day $(460.91 \pm 29.17 \mathrm{mg} / \mathrm{dl})$ were statisitically higher than those of the baseline $(90.10 \pm 12.61 \mathrm{mg} / \mathrm{dl}) \quad(p<0.05)$ (data not shown).

\section{Histopathologic Assesment}

Control groups were revealed no resorptive lacunae and osteoclast in each study periods (Figure 1). Number of resorptive lacunea and osteoclast in the AG groups ( $A G, A G+O z o n e)$ was significantly higher than those of the Control groups in both 4th, 8th week ( $p$ $<0.05$ ). There was no statistically significance between $A G$ and $A G+O z o n e$ groups at 4 th and 8th weeks ( $p>0.05)$ regarding to resorptive lacunae. But, osteoclast numbers in $A G+O z o n e$ group were significantly increased at 8 th week comparing to 4 th week $(p<0.05)$.

The Control+Ozone group showed more osteoblasts comparing to Control group at 4th week $(p>0.05)$ (Figure 2). AG groups (AG, AG+Ozone) were found statistically higher osteoblasts than those of the Control groups (Control, Control+Ozone) both 4th and 8th week $(p<0.05)$. Osteoblasts in $A G+O z o n e$ group were higher than $A G$ group at 4th week $(p>0.05)$. There were no statistically significant differences comparing all groups at 8th week in terms of osteoblast numbers ( $p>0.05)$. 

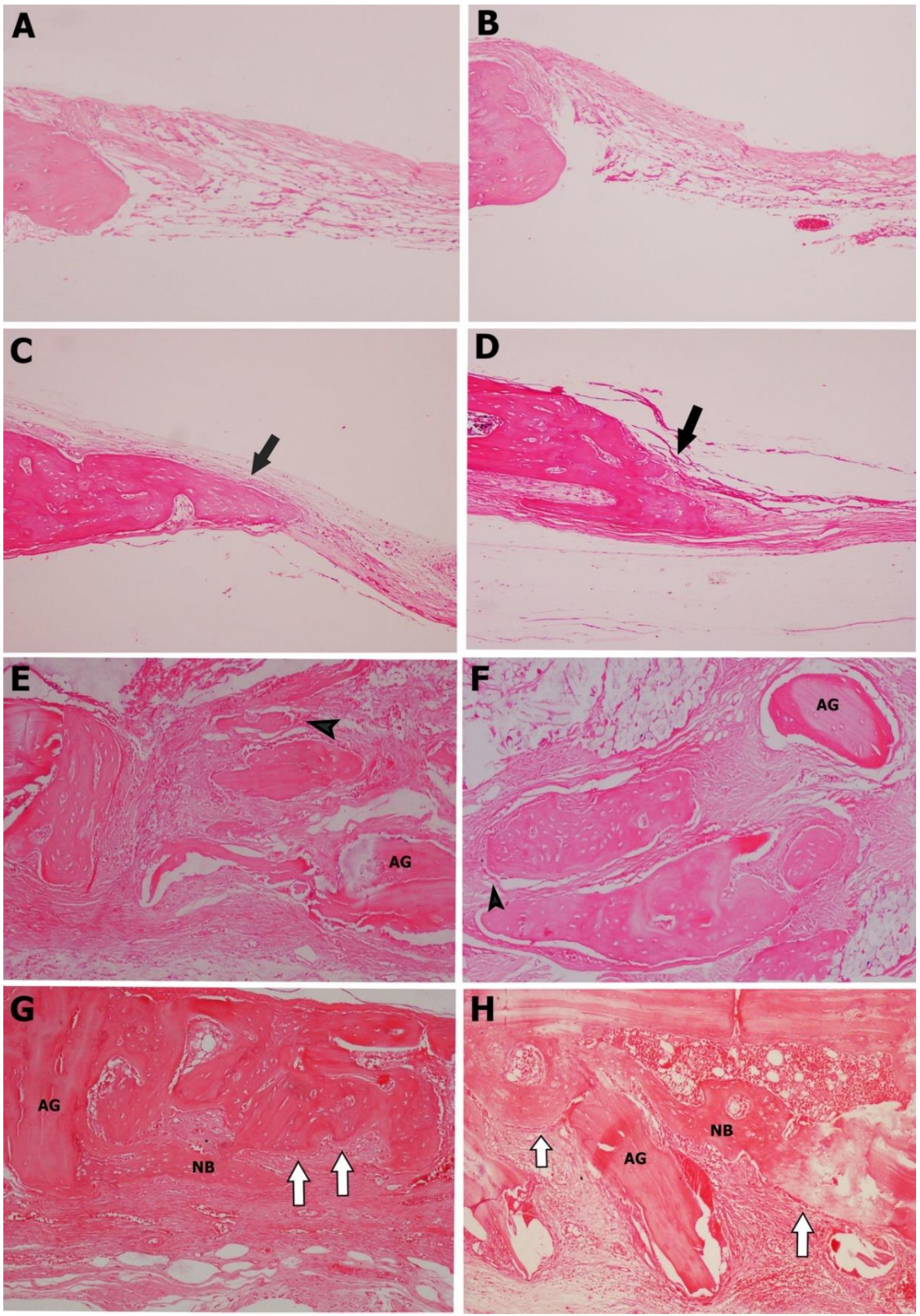

Figure 1.

Histologic picture of the groups at 4th and 8th weeks (H\&E, original magnification x100)

(A) Defect healing with fibrous connective tissue in Control group at 4th week (H\&E, original magnification x100)

(B) Defect healing with fibrous connective tissue in Control group at 8th week

(C) New bone ingrowth in Control+Ozone group at 4th week (black arrow)

(D) New bone ingrowth in Control+Ozone group at 8th week (black arrow)

(E) Osteoclastic activity with resorptive lacunae at autogenous bone graft border at 4th week in AG group (short black arrow)

(F) Osteoclastic activity with resorptive lacunae at autogenous bone graft border at 8th week in AG group (short black arrow)

(G) Acceraleted osteoblastic activity adjacent the new bone and new bone formation in AG+Ozone group at 4th week (white arrow),

(H) Acceraleted osteoblastic activity adjacent the new bone and new bone formation in AG+Ozone group at 8th week (white arrow).

AG-Autogenous bone graft, NB-New bone 

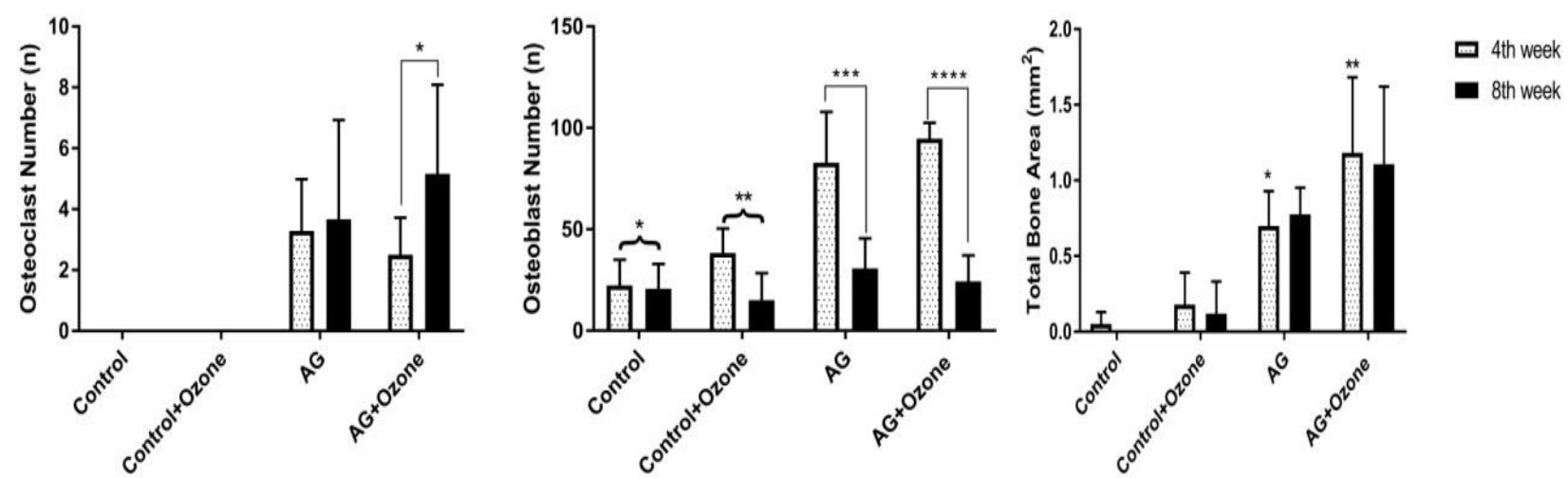

Figure 2.

Mean osteoclast, osteoblast and total bone area of the groups at 4th and 8th weeks.

Osteoclast numbers: Control and Control+Ozone groups revealed no osteoclast at 4th and 8th week. * p $<0.05$

Osteoclast number of AG+Ozone group increased at 8 th week. Osteoblast numbers: * $p<0.05$

Control group revealed less osteoblast number both 4th and 8th week comparing to AG+Ozone group at 4th week; ** $\mathrm{p}<0.05$,

Control+Ozone group revealed less osteoblast number both 4th and 8th week comparing to AG+Ozone group at 4th week; ***p $<0.05$

Osteoblast in AG group at 4th week decreased at 8th week; **** $\mathrm{p}<0.05$

Osteoblast in AG+Ozone group at 4th week decreased at 8th week

Total bone area: * $\mathrm{p}<0.05$, AG group revealed more total bone area than Control and Control+Ozone groups at 4th week; AG+Ozone group had

more total bone area than AG, Control, Control+Ozone group at 4th week

\section{Histomorphometric assesment}

The AG groups (AG, AG+Ozone) were revealed more total bone area than Control groups at both 4 th and 8th week $(p<0.05)$. $A G+$ Ozone groups had more total bone area than those of the $A G$ group at 4 th week $(p<0.05)$ and 8th week $(p>0.05)$ (Figure 2).

\section{BMP-2 expression and localization}

$A G$ and Control groups showed immunoexpression of BMP-2 at both 4th and 8th weeks (Figure 3 ). The BMP-2 positive cells more prominent localization found at osteoblasts and mesenchymal tissue in AG+Ozone group. Contol groups were revealed some weak to moderate BMP-2 staining at the some of the osteoblasts in the mesenchymal tissue. BMP-2 expression in groups was decreased at 8th week and localized at mesenchymal tissue at the defect border (Figure 4 A,B,C,D).

\section{Osteocalcin expression and localization}

$A G$ and Control groups showed immunoexpression of osteocalcin at both 4th and 8th weeks (Figure 3). AG groups showed higher expression of osteocalcin than the Control group at 4th week. In $A G+$ Ozone group were revealed strong positive expression for osteocalcin at the new bone matrix suggesting active bone matrix production at 4 th week. Osteocalcin positive cells percenteges in all groups were similar and prominently detected at osteocyte, osteoblast and soft tissue extracelluler matrix at 8th week (Figure 4 $E, F, G, H)$.
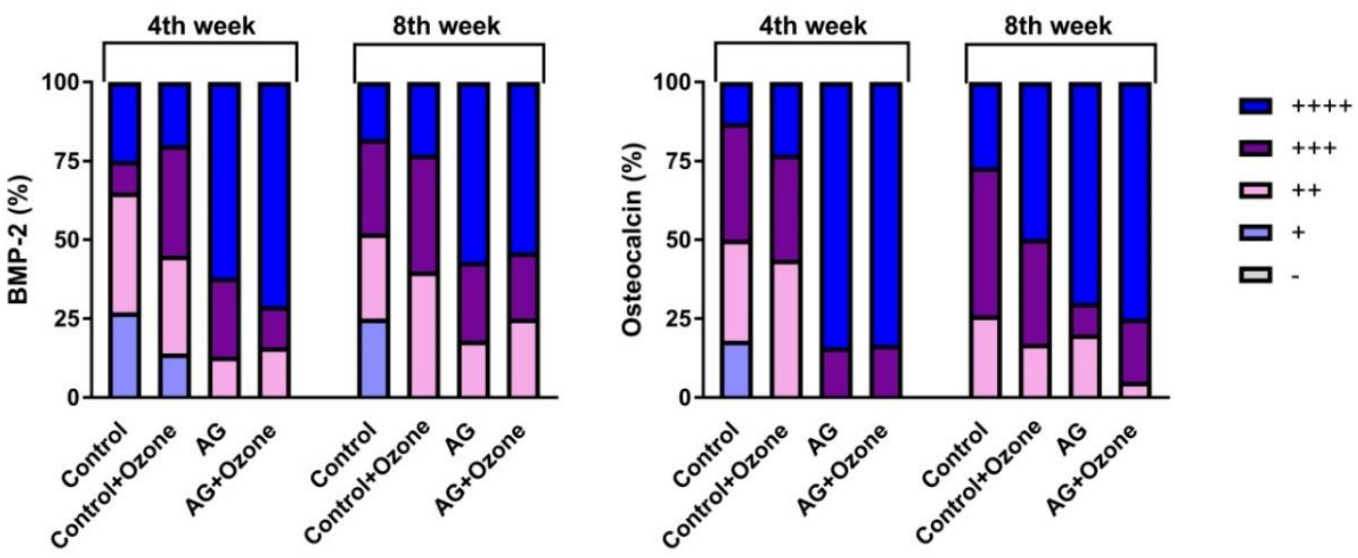

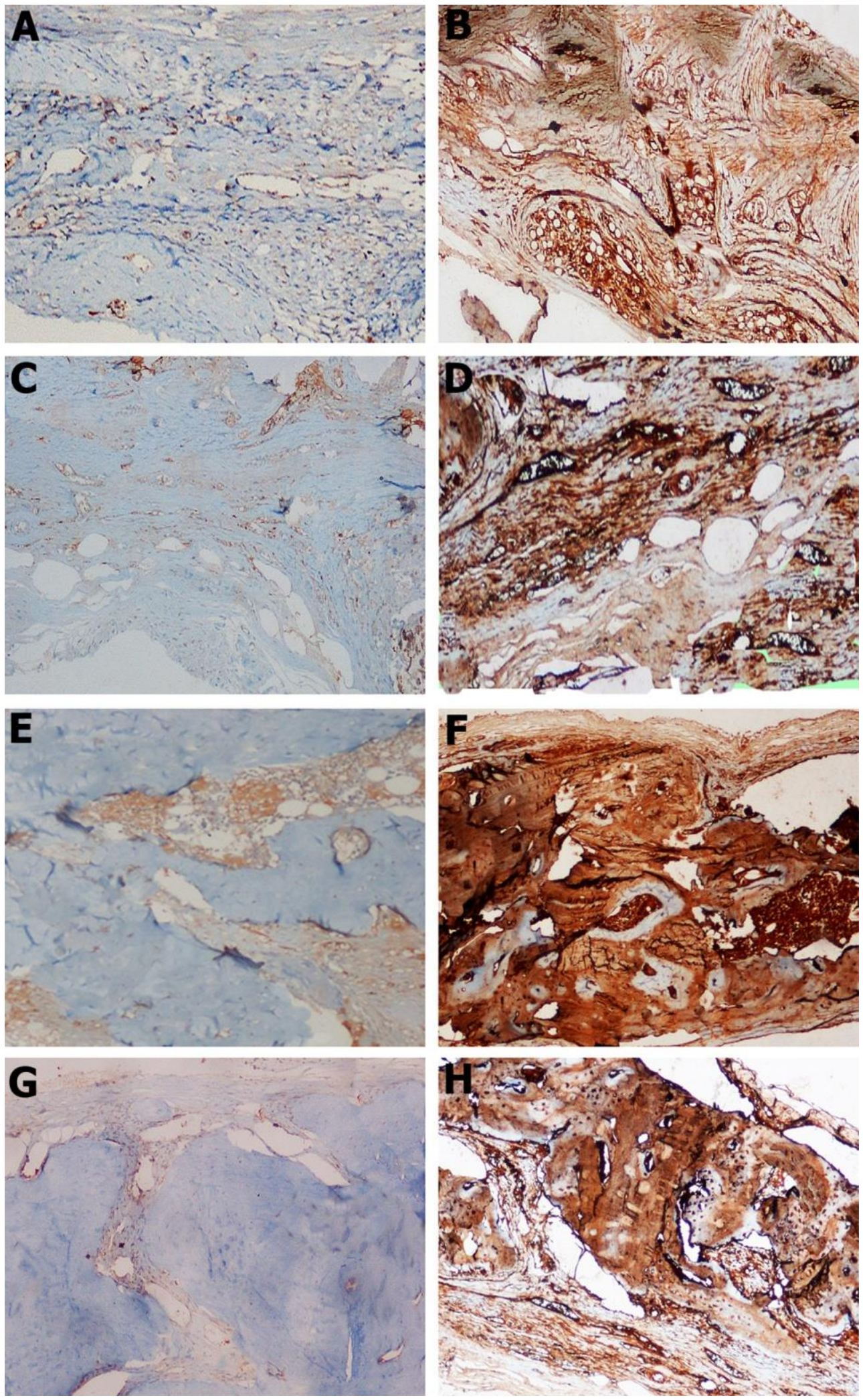

Figure 4.

Immunostaining levels in situ BMP-2 with blue panel and Osteocalcin with brown panel (original magification x100) at 4th week; BMP-2 immunostaining : Control(A),Control+Ozone(C), AG(E), AG+Ozone(G) and Osteocalcin immunostainin: Control(B), Control+Ozone(D), AG(F), AG+Ozone(H) expression. All groups were revealed positive immunostaining both BMP-2 and Osteocalcin. Immunohistochemistry revealed increased BMP-2 (G) and osteocalcin $(\mathrm{H})$ in sites in $\mathrm{AG}+\mathrm{Ozone}$ group 


\section{DISCUSSION}

In this present study, we investigated the effects of gaseous ozone treatment on bone regeneration in diabetic rat calvarial defect model. We demonstrated that early stages of bone regeneration are accerelated in ozone applied autogenous bone graft group in the presence of diabetic state.

In literature, many models have been used to induce diabetes. ${ }^{21-23}$ Preclinical rodent models that manifest DM using streptozotocin has been well established. ${ }^{24}$ STZ and alloxan are the most commonly used drugs for pharmacological induction. Both drugs can show their effects with parenteral, intravenous, intraperitoneal and subcutaneous administration. The administration doses of these drugs depend on the animal species, the route of administration and the nutritional status. ${ }^{25}$ STZ administration is now more preferred because it is more specific than alloxan, which leads to less ketosis in the animal and the difference between the experimental animals in terms of effective dose is less. Apart from these, STZ is nephrotoxic in humans, but changes in renal morphology in animals are due to slow developing complications due to diabetes rather than chemical toxicity of the drug ${ }^{26-28}$. In this study, one single dose STZ $(50 \mathrm{mg} / \mathrm{kg})$ was injected to rats intraperitoneally, after 3 diabetes was induced in all rats and lasted during the study. Furthermore, weight loss was continued in all rats during the study.

CSD defined the smallest size bone defect that do not report spontaneous healing during the lifetime of the animal. ${ }^{29}$ This kind of defect heals by fibrous connective tissue rather than bone fill. In literature, controversial data regarding the dimensions of CSD have been reported. ${ }^{30-33} \mathrm{In}$ this present study, $5 \mathrm{~mm}$ diameter defect used as CSD and defect fill did not occur in Control groups both at 4th and 8th week.

Gorla et $\mathrm{al}^{34}$ compared the changes in bone volume after maxillary sinus lifting using autogenous bone, autogenous bone associated with beta tricalcium phosphate and beta tricalcium phosphate alone as grafting material. Autogenous bone showed the highest resorption rate $(45.7 \pm 18.6 \%)$ by means of cone beam computed tomography. Furthermore, diabetes impairs bone metabolism and one study found that cancellous bone volume and bone formation in the femur were greatly reduced in the diabetic model. ${ }^{35}$ Also, diabetic rats with periodontitis have a two- to fourfold increase in the number of osteoclasts. ${ }^{36}$ Despite hyperglycemia-inhibited osteoblast differentiation and activity ${ }^{37}$ also diabetes-depended dysregulation as well as reduced insulin signaling may lead to increased osteoclast formation. ${ }^{2}$ In our study ozone application decreased osteoclast number at 4th week. However at 8th week AG+Ozone group revealed significantly higher osteoclasts and lesser osteoblasts than 4th week. This result may be explained that the inadequate ozone dosages and application time to eliminate diabetic conditions during 8 week.

Ozone can react with components of the vascular system elements such as erythrocytes, leukocycytes, platelets and endothelial cells, improve oxygen metabolism, cell energy, anioxidant defence system and microcirculation in tissues. ${ }^{16}$ Based on this favorable effects of ozone some researchers suggest that the ozone therapy may be usefull for bone regeneration process.

In the first study from our groups about ozone therapy ${ }^{10}$ was evaluated gasseous ozone efficacy on autograft healing in rats. CSD were created and the rats were divided into 3 groups following; the contol, the autogenous bone and the autogenous bone combined ozone therapy groups. Ozone was applied gasseous form using by a generator $(80 \%, 30$ second, every 3 days for 2 weeks). We concluded that osteoblast number, total bone area were increased in autogenous bone combined with ozone group compared to other groups. Also, in diabetic state, we found that ozone therapy were increased osteblast number Another study performed with ozone, ozone efficacy was compared to low level laser therapy efficacy. CSD were created and filled with biphasic calcium phosphate graft material. Gasseous ozone was applied using by a generator (80\%, 120 seconds per day, 3 days per week for 2 weeks). At the end of the study ozone group had more new bone area comparing to other groups. Authors concluded that the ozone application at least as effective as low level laser application. Also Kan et $\mathrm{al}^{38}$ investigated effect of systemic ozone usage and hyperbaric oxygen on calvarial defect healing. Ozone was applied via intraperitoneally injection $\left(97 \% \mathrm{O}_{2}+\right.$ $3 \% \quad \mathrm{O}_{3}$, once a day for 5 days). According to histomorphometric and microtomographic evaluation, experimental groups showed higher new bone volumes compared to controls. They concluded that the systemic ozone application to be as effective as hyperbaric oxygen treatment in promoting the bone healing of CSD.

BMP-2 is belong the BMP family and since the identification BMP-2 as a potent inducer of bone and cartilage formation ${ }^{39}$ but hyperglicemic condition may reduce BMP-2 expression is associated with nuclear factor kappa B. ${ }^{40,41}$ In this recent study, the $A G+O z o n e$ group showed more intense immunpositivity in osteoblasts and mesenchymal tissue for BMP-2 in samples consistent with data from histomorphometry at 4th week. Furthermore, osteocalcin is a bone matrix protein also that has been associated with energy and glucose 
metabolism. ${ }^{42}$ There is conflicting results in term of osteocalcin levels in diabetic condition. ${ }^{43,44}$ Although diabetes lasted during the study period, the immunnohistochemical analyses demonstrated that the more intense expression of osteocalcin was observed in new bone and defect border in the $A G+$ Ozone group.

\section{CONCLUSION}

In conclusion, within the limitations of this animal study, gaseous ozone application decreased osteoclastogenesis and enhanced bone regeneration at early stages of healing in diabetes mellitus. However, further studies should investigate the effect of different dosages and application times of ozone to elimination of diabetic bone healing complications. And, also, the potential mechanism of action of ozone on bone regeneration should be elucidated. 


\section{REFERENCES}

1. Gurav AN. Management of diabolical diabetes mellitus and periodontitis nexus: Are we doing enough? World J Diabetes. 2016; 7(4): 50-66.

2. Jiao H, Xiao E, Graves DT. Diabetes and Its Effect on Bone and Fracture Healing. Curr Osteoporos Rep. 2015; 13(5): 327-35.

3. Daugela P, Cicciu M, Saulacic N. Surgical Regenerative Treatments for Peri-Implantitis: Metaanalysis of Recent Findings in a Systematic Literature Review. J Oral Maxillofac Res. 2016; 7(3): e15.

4. Dimitriou R, Jones E, McGonagle D, Giannoudis PV. Bone regeneration: current concepts and future directions. BMC Med. 2011; 9: 66.

5. Yin W, Qi X, Zhang Y, Sheng J, Xu Z, Tao S, et al. Advantages of pure platelet-rich plasma compared with leukocyte- and platelet-rich plasma in promoting repair of bone defects. J Transl Med. 2016; 14(1): 73.

6. Peng W, Kim IK, Cho HY, Pae SP, Jung BS, Cho $\mathrm{HW}$, et al. Assessment of the autogenous bone graft for sinus elevation. J Korean Assoc Oral Maxillofac Surg. 2013; 39(6): 274-82.

7. Keskiner I, Alkan A, Acikgoz G, Arpak N, Kaplan S, Arslan $\mathrm{H}$. Platelet-rich plasma and autogenous bone graft combined with guided tissue regeneration in periodontal fenestration defects in dogs. Int $\mathrm{J}$ Periodontics Restorative Dent. 2014; 34(6): e112-20.

8. Kokdere NN, Baykul T, Findik Y. The use of plateletrich fibrin (PRF) and PRF-mixed particulated autogenous bone graft in the treatment of bone defects: An experimental and histomorphometrical study. Dent Res J (Isfahan). 2015; 12(5): 418-24.

9. Toker H, Ozdemir H, Ozer H, Eren K. Alendronate enhances osseous healing in a rat calvarial defect model. Arch Oral Biol. 2012; 57(11): 1545-50.

10. Ozdemir H, Toker $\mathrm{H}$, Balci $\mathrm{H}$, Ozer $\mathrm{H}$. Effect of ozone therapy on autogenous bone graft healing in calvarial defects: a histologic and histometric study in rats. J Periodontal Res. 2013; 48(6): 722-6.

11. Abelev B, Adam J, Adamova D, Adare AM, Aggarwal MM, Aglieri Rinella G, et al. J/psi suppression at forward rapidity in $\mathrm{Pb}-\mathrm{Pb}$ collisions at radicals(NN) $=2.76$ TeV. Phys Rev Lett. 2012; 109(7): 072301.

12.Bocci VA. Scientific and medical aspects of ozone therapy. State of the art. Arch Med Res. 2006; 37(4): 425-35.

13. Huth KC, Jakob FM, Saugel B, Cappello C, Paschos E, Hollweck R, et al. Effect of ozone on oral cells compared with established antimicrobials. Eur J Oral Sci. 2006; 114(5): 435-40.

14. Nagayoshi M, Fukuizumi T, Kitamura C, Yano J, Terashita M, Nishihara T. Efficacy of ozone on survival and permeability of oral microorganisms. Oral Microbiol Immunol. 2004; 19(4): 240-6.
15. Huth KC, Quirling M, Lenzke S, Paschos E, Kamereck K, Brand K, et al. Effectiveness of ozone against periodontal pathogenic microorganisms. Eur J Oral Sci. 2011; 119(3): 204-10.

16. Kazancioglu HO, Ezirganli S, Aydin MS. Effects of laser and ozone therapies on bone healing in the calvarial defects. J Craniofac Surg. 2013; 24(6): 2141-6.

17. Kazancioglu HO, Kurklu E, Ezirganli S. Effects of ozone therapy on pain, swelling, and trismus following third molar surgery. Int $\mathrm{J}$ Oral Maxillofac Surg. 2014; 43(5): 644-8.

18. Erdemci F, Gunaydin Y, Sencimen M, Bassorgun I, Ozler M, Oter S, et al. Histomorphometric evaluation of the effect of systemic and topical ozone on alveolar bone healing following tooth extraction in rats. Int J Oral Maxillofac Surg. 2014; 43(6): 777-83.

19.Lektemur Alpan A, Toker H, Ozer H. Ozone Therapy Enhances Osseous Healing In Diabetic Rats With Calvarial Defect: A Morphometric and Immunohistochemical Study. J Periodontol. 2016: 1-15.

20.Deliberador TM, Giovanini AF, Lopes TR, Zielak JC, Moro A, Baratto Filho $F$, et al. Immunoexpression of PPAR-gamma and osteocalcin proteins for bone repair of critical-size defects treated with fragmented autogenous abdominal adipose tissue graft. Braz Dent $\mathrm{J}$. 2014; 25(3): 179-85.

21. Kumar V, Mahdi F, Khanna AK, Singh R, Chander R, Saxena JK, et al. Antidyslipidemic and Antioxidant Activities of Hibiscus rosa sinensis Root Extract in Alloxan Induced Diabetic Rats. Indian J Clin Biochem. 2013; 28(1): 46-50.

22. Mohammadi Sartang M, Mazloomi SM, Tanideh $\mathrm{N}$, Rezaian Zadeh A. The Effects of Probiotic Soymilk Fortified with Omega-3 on Blood Glucose, Lipid Profile, Haematological and Oxidative Stress, and Inflammatory Parameters in Streptozotocin Nicotinamide-Induced Diabetic Rats. J Diabetes Res. 2015; 2015: 696372.

23.Islam MS, Loots du T. Experimental rodent models of type 2 diabetes: a review. Methods Find Exp Clin Pharmacol. 2009; 31 (4): 249-61.

24.Srinivas NR. Strategies for preclinical pharmacokinetic investigation in streptozotocininduced diabetes mellitus (DMIS) and alloxaninduced diabetes mellitus (DMIA) rat models: case studies and perspectives. Eur J Drug Metab Pharmacokinet. 2015; 40(1): 1-12.

25. Frode TS, Medeiros YS. Animal models to test drugs with potential antidiabetic activity. J Ethnopharmacol. 2008; 115(2): 173-83. 
26.Ishibashi T, Tanaka K, Taniguchi Y. Platelet aggregation and coagulation in the pathogenesis of diabetic retinopathy in rats. Diabetes. 1981; 30(7): 601-6.

27.Valentovic MA, Alejandro N, Betts Carpenter A, Brown PI, Ramos K. Streptozotocin (STZ) diabetes enhances benzo(alpha)pyrene induced renal injury in Sprague Dawley rats. Toxicol Lett. 2006; 164(3): 214-20.

28.Lei YC, Hwang JS, Chan CC, Lee CT, Cheng TJ. Enhanced oxidative stress and endothelial dysfunction in streptozotocin-diabetic rats exposed to fine particles. Environ Res. 2005; 99(3): 335-43.

29.Schmitz JP, Hollinger JO. The critical size defect as an experimental model for craniomandibulofacial nonunions. Clin Orthop Relat Res. 1986(205): 299308.

30.Freeman E, Turnbull RS. The value of osseous coagulum as a graft material. J Periodontal Res. 1973; 8(4): 229-36.

31.Petridis X, Diamanti E, Trigas G, Kalyvas D, Kitraki $E$. Bone regeneration in critical-size calvarial defects using human dental pulp cells in an extracellular matrix-based scaffold. J Craniomaxillofac Surg. 2015; 43(4): 483-90.

32.Vo TN, Ekenseair AK, Spicer PP, Watson BM, Tzouanas SN, Roh TT, et al. In vitro and in vivo evaluation of self-mineralization and biocompatibility of injectable, dual-gelling hydrogels for bone tissue engineering. J Control Release. 2015; 205: 25-34.

33. Abreu TC, Lima RP, Souza VS, Campos Junior O, Albuquerque AV, Aguiar JL, et al. The biopolymer sugarcane as filling material of critical defects in rats. Acta Cir Bras. 2016; 31(1): 53-8.

34.Gorla LF, Spin-Neto R, Boos FB, Pereira Rdos S, Garcia-Junior IR, Hochuli-Vieira E. Use of autogenous bone and beta-tricalcium phosphate in maxillary sinus lifting: a prospective, randomized, volumetric computed tomography study. Int J Oral Maxillofac Surg. 2015; 44(12): 1486-91.

35.Shyng YC, Devlin $H$, Sloan $P$. The effect of streptozotocin-induced experimental diabetes mellitus on calvarial defect healing and bone turnover in the rat. Int $\mathrm{J}$ Oral Maxillofac Surg. 2001; 30(1): 70-4.

36.Pacios S, Kang J, Galicia J, Gluck K, Patel H, Ovaydi-Mandel A, et al. Diabetes aggravates periodontitis by limiting repair through enhanced inflammation. FASEB J. 2012; 26(4): 1423-30.

37.Lu H, Kraut D, Gerstenfeld LC, Graves DT. Diabetes interferes with the bone formation by affecting the expression of transcription factors that regulate osteoblast differentiation. Endocrinology. 2003; 144(1): 346-52.
38.Kan B, Sencimen M, Bayar GR, Korkusuz P, Coskun AT, Korkmaz A, et al. Histomorphometric and microtomographic evaluation of the effects of hyperbaric oxygen and systemic ozone, used alone and in combination, on calvarial defect healing in rats. J Oral Maxillofac Surg. 2015; 73(6): 1231 e1-10.

39. Salazar VS, Gamer LW, Rosen V. BMP signalling in skeletal development, disease and repair. Nat Rev Endocrinol. 2016; 12(4): 203-21.

40.Pacios S, Andriankaja O, Kang J, Alnammary M, Bae J, de Brito Bezerra B, et al. Bacterial infection increases periodontal bone loss in diabetic rats through enhanced apoptosis. Am J Pathol. 2013; 183(6): 1928-35.

41. Sarkar PD, Choudhury AB. Relationships between serum osteocalcin levels versus blood glucose, insulin resistance and markers of systemic inflammation in central Indian type 2 diabetic patients. Eur Rev Med Pharmacol Sci. 2013; 17(12): 1631-5.

42.Zanatta LC, Boguszewski CL, Borba VZ, Kulak CA. Osteocalcin, energy and glucose metabolism. Arq Bras Endocrinol Metabol. 2014; 58(5): 444-51.

43. Starup-Linde J, Vestergaard P. Biochemical bone turnover markers in diabetes mellitus - A systematic review. Bone. 2015.

44. Roszer T. Inflammation as death or life signal in diabetic fracture healing. Inflamm Res. 2011; 60(1): 3-10.

\section{Corresponding Author:}

Aysan LEKTEMUR ALPAN
Pamukkale University
Psikiyatri Hastanesi Arkası (Eski Fizik Tedavi Binası)
Kınıklı Kampüsü, 20070, Denizli, Turkey
Phone : +90 5053890608
Fax : +90 2582961763
E-mail : ysnlpn@gmail.com

